\title{
Diagnostic Alternatives Used by Veterinary Surgeons for the Recording of Udder Diseases in the Norwegian Health Card System for Cattle
}

\author{
By S. Sviland and S. Waage \\ National Veterinary Institute, Oslo, Norway.
}

\begin{abstract}
Sviland S, Waage S: Diagnostic alternatives used by veterinary surgeons for the recording of udder diseases in the Norwegian Health Card System for Cattle. Acta vet. scand. 2000, 41, 261-271. - A questionnaire, in which 7 cases of udder disease were described, was distributed to 890 veterinarians in Norway. They were requested to classify the cases according to the diagnostic alternatives listed in the Norwegian Health Card System for Cattle (NHCSC). The NHCSC recordings are used for progeny testing of bulls, for disease monitoring, and for research purposes. The aim of this study was to evaluate the quality of the recordings for udder diseases. The questionnaire was answered by 633 veterinary surgeons. Four cases of clinical mastitis (CM) with abnormal secretion as well as other clinical signs of inflammation were correctly classified as $\mathrm{CM}$ by almost $100 \%$ of the veterinary surgeons. A cow in the final stage of lactation, showing no clinical signs except for clots in the milk, was considered not to be a clinical case by more than $25 \%$ of the veterinary surgeons. A typical case of subclinical mastitis (SM) was reported as SM by $83 \%$ of the veterinary surgeons, and as CM by $16 \%$. A subclinical case with a recent history of clots in the secretion was classified as SM by $66 \%$ of the veterinary surgeons, but almost $40 \%$ either reported $\mathrm{CM}$ as their sole diagnosis or considered the case to be CM in combination with SM. Of the clinical cases, those exhibiting marked local signs of inflammation and a systemic reaction were correctly classified as acute clinical mastitis (ACM) by $96 \%-98 \%$ of the veterinary surgeons. In the NHCSC, the diagnostic alternatives for cases of CM are ACM and chronic clinical mastitis (CCM). One case, for which the diagnosis subacute clinical mastitis was appropriate according to standard definitions, was classified as CCM by $66 \%$, and as ACM by $6 \%$. Based on the information given in the questionnaire, the diagnosis for 2 of the clinical cases could have been either ACM or CCM, and for both cases each of these 2 alternatives was reported by more than $43 \%$ of the veterinary surgeons. A teat lesion, which was present together with ACM in one cow, was reported by $91 \%$ of the veterinary surgeons.
\end{abstract}

cow; disease recording.

\section{Introduction}

The Norwegian Health Card System for Cattle (NHCSC) was introduced in 1975. All cows in dairy herds that participate in the National Production Recording Scheme are also enrolled in the NHCSC. The purpose of the NHCSC is to register, at an individual animal level, all incidents of disease in dairy herds.
All cows have individual health cards giving the identity of the herd and of the cow and its parents, as well as the date of birth of the cow. Having diagnosed a disease or abnormal condition in a cow, the veterinary surgeon records the code of the diagnosis, the date of examination, and his/her veterinary identity number on the 
health card. These recordings are regularly reported to a central database.

The data supply valuable information on the disease situation in the particular herd and are also employed for disease monitoring and research purposes as well as in the progeny testing of bulls selected for artificial insemination. The quality of the recordings is therefore of considerable interest. The recording of cases and the classification of diseases are crucial points in the registration process. In Norway, regulations regarding the sale of antibiotics and other drugs ensure that most cases of disease in food producing animals are treated by veterinary surgeons. The extent to which cases of disease are registered will, therefore, largely depend on the loyalty of the veterinary surgeons to the system.

The list of diagnostic alternatives in the NHCSC is a compromise between the need for a well-nuanced repertoire of diagnoses and the fact that diagnoses are normally based on routine clinical examination of cases using diagnostic tools that are commonly applied under field conditions. In the NHCSC, mastitis is designated either as acute clinical mastitis (ACM), chronic clinical mastitis (CCM), or subclinical mastitis (SM). Although not entirely in accord, the definitions of the different forms of mastitis given in the literature agree to a large extent (Schalm et al. 1971, International Dairy Federation 1987, National Mastitis Council 1996). The definitions presented to the students at the Norwegian School of Veterinary Science (Anonymous 1991) are essentially the same as given by Schalm et al. (1971). Cases of mastitis are usually easy to diagnose, although some uncertainty may arise around parturition when udder oedema and changes in the appearance of the secretion may be present in normal heifers and cows. However, the further classification of a case of mastitis may pose problems under certain circumstances. For example, it may some- times be difficult to decide whether or not a case is chronic.

In some countries, disease frequencies, reproduction, and productivity of individual food producing animals, as well as factors related to the environment and management in the herd, are monitored by gathering information from selected farmers in certain areas by means of mailed questionnaires or interview questionnaires. Studies have been carried out using testretest questionnaires to assess the repeatability of information supplied in answers in questionnaire studies. In 2 studies, the overall discrepancy between answers in the first and the second test was $13.4 \%$ and $8.5 \%$, respectively (Schukken et al. 1989, Erb et al. 1996).

In the NHCSC, cases of disease are diagnosed and recorded by veterinary surgeons. It seems reasonable to expect that this arrangement will increase the likelihood of correct diagnoses and proper recording as compared with a system in which the farmer is responsible for the registration of diseases.

In the present study, descriptions of several cases of mastitis were presented to veterinary surgeons that were requested to make their diagnoses according to the NHCSC alternatives. The purpose was to examine the extent to which there was mutual agreement between veterinary surgeons with regard to diagnostic choices, and how these harmonised with the standard definitions of the different forms of mastitis.

\section{Materials and methods}

\section{Study design}

Written descriptions of 7 cases of bovine udder disease, accompanied by an information letter, were mailed to 890 veterinarians in Norway. The veterinary surgeons were requested to make one or more diagnoses for each case and, of the alternatives available in the NHCSC, use those they would have chosen and recorded for 
similar cases in the NHCSC in their ordinary practice. In addition, they were asked to state whether they were occupied full-time or parttime in large animal practice, and also to indicate in which county they were practising. No information was given on the definitions of the various forms of mastitis. The questionnaire was sent to all veterinarians on the mailing list of «Sperma», a journal published jointly by the Norwegian Dairies Association and the Norwegian Red Cattle Breeding Organisation. The mailing list included not only the veterinary surgeons that we intended to include in the study, i. e., those who carried out at least one artificial insemination or had registered at least 5 diagnoses in the NHCSC during the previous year, but also a number of non-practising veterinarians who were engaged in teaching or governmental administration work. A stamped envelope for the return of the completed questionnaires was enclosed. A second request was mailed approximately 6 weeks later to those who did not respond to the first letter.

Completed forms were received from 633 $(71.1 \%)$ of the veterinary surgeons. Of these, 570 supplied information whether they practised full-time or part-time and in which county they practised, 29 on only county of practice, 25 on only extent of practice, and 9 on neither county nor extent of practice. Twelve had stopped practising and returned the letter with no answers at all.

Of the veterinary surgeons that supplied information on the extent of their practice, $82.1 \%$ were engaged full-time. The percentage of veterinary surgeons answering the questionnaire was 35 in Oslo and Akershus counties, and between 61 and 88 in the remaining counties.

\section{Definitions}

The following definitions of different forms of mastitis are based on Schalm et al. (1971), International Dairy Federation (Anon. 1987), and National Mastitis Council (Anon. 1996). Subclinical mastitis is characterised by inflammatory changes in the milk that can be detected by special tests, but there are no detectable changes in the udder or observable abnormalities in the secretion. Clinical mastitis is either accompanied by visible change in the secretion, clinical signs of changes in the udder, or both. Subacute clinical mastitis is characterised by observable changes in the secretion, while clinical signs of inflammation of the udder (heat, swelling, and pain) are slight or absent. There are no systemic signs. Acute clinical mastitis is characterised by a sudden onset and the presence of one or more of the cardinal signs of inflammation. Systemic signs may be present. When the onset is very rapid and symptoms very severe, the condition is termed peracute clinical mastitis. Chronic clinical mastitis is a clinical condition of long duration with visible abnormal secretion or progressive development of fibrous tissue.

\section{Diagnostic alternatives}

The veterinary surgeons that participated in the study were requested to use the diagnostic alternatives for udder diseases that are available in the NHCSC, the alternatives for mastitis being $\mathrm{ACM}, \mathrm{CCM}$, and SM. In addition, separate diagnostic codes exist for teat lesion and "other diseases of the udder and teats".

\section{Description of cases}

Seven cases of udder disease were described, in which one or more of the conditions ACM, subacute clinical mastitis, CCM, SM, and teat lesion were present. Importance was attached to making the described cases represent cases that appear in the field. No attention was paid to the definitions of the mastitis forms. In the descriptions, the California Mastitis Test (CMT) reaction was graded from 1 to 5 according to Klastrup \& Schmidt Madsen (1974) and listed in the 
Table 1. Percentage distribution of diagnoses made by 633 veterinary surgeons for 7 theoretical cases of udder disease. The diagnostic alternatives, corresponding with the alternatives of the Norwegian Health Card System for Cattle, were acute clinical mastitis (ACM), chronic clinical mastitis (CCM), subclinical mastitis (SM), teat lesion (TL), and other diseases of the udder or teats (Other). The number of diagnoses per case given by the veterinary surgeons was either none, 1,2 , or 3 .

\begin{tabular}{|c|c|c|c|c|c|c|c|}
\hline Diagnosis & Case 1 & Case 2 & Case 3 & Case 4 & Case 5 & Case 6 & Case 7 \\
\hline None & 0 & 0 & 0.3 & 0.2 & 0.6 & 2.7 & 1.9 \\
\hline ACM & 36.3 & 8.4 & 37.3 & 67.9 & 0.2 & 4.9 & 0.6 \\
\hline $\mathrm{CCM}$ & 47.1 & 0 & 50.4 & 2.5 & 31.3 & 59.4 & 11.7 \\
\hline SM & 0.2 & 0 & 1.4 & 0.6 & 58.0 & 23.5 & 77.9 \\
\hline TL & 0 & 0.9 & 0 & 0 & 0.5 & 0.2 & 0.8 \\
\hline Other & 0.2 & 0 & 0.8 & 0 & 0.5 & 1.4 & 1.9 \\
\hline Sum one diagnosis & 83.8 & 9.3 & 89.9 & 71.0 & 90.5 & 89.4 & 92.9 \\
\hline $\mathrm{ACM}+\mathrm{CCM}$ & 10.9 & 0.5 & 4.6 & 22.6 & 0 & 0 & 0 \\
\hline $\mathrm{ACM}+\mathrm{SM}$ & 1.7 & 0.3 & 0.8 & 5.2 & 0.2 & 0.6 & 0.3 \\
\hline $\mathrm{ACM}+\mathrm{TL}$ & 0 & 86.1 & 0.2 & 0 & 0 & 0 & 0 \\
\hline $\mathrm{ACM}+$ other & 0 & 0.3 & 0.6 & 0 & 0 & 0 & 0 \\
\hline $\mathrm{CCM}+\mathrm{SM}$ & 3.0 & 0 & 1.1 & 0.3 & 8.1 & 6.2 & 3.9 \\
\hline $\mathrm{CCM}+\mathrm{TL}$ & 0 & 0.5 & 0.3 & 0 & 0 & 0 & 0 \\
\hline $\mathrm{CCM}+$ other & 0 & 0 & 2.2 & 0 & 0.3 & 0.5 & 0 \\
\hline $\mathrm{SM}+\mathrm{TL}$ & 0 & 0.3 & 0 & 0 & 0 & 0 & 0 \\
\hline SM+other & 0 & 0 & 0 & 0 & 0.3 & 0.5 & 0.9 \\
\hline TL+other & 0 & 0.2 & 0 & 0 & 0 & 0 & 0 \\
\hline Sum two diagnoses & 15.6 & 88.2 & 9.8 & 28.1 & 8.9 & 7.8 & 5.1 \\
\hline $\mathrm{ACM}+\mathrm{CCM}+\mathrm{SM}$ & 0.6 & 0 & 0 & 0.6 & 0.2 & 0 & 0 \\
\hline $\mathrm{ACM}+\mathrm{CCM}+\mathrm{TL}$ & 0 & 0.3 & 0 & 0 & 0 & 0 & 0 \\
\hline $\mathrm{ACM}+\mathrm{SM}+\mathrm{TL}$ & 0 & 1.7 & 0 & 0 & 0 & 0 & 0 \\
\hline $\mathrm{ACM}+\mathrm{TL}+$ other & 0 & 0.5 & 0 & 0 & 0 & 0 & 0 \\
\hline $\mathrm{CCM}+\mathrm{SM}+$ other & 0 & 0 & 0 & 0 & 0 & 0.2 & 0 \\
\hline Sum three diagnoses & 0.6 & 2.5 & 0 & 0.6 & 0.2 & 0.2 & 0 \\
\hline Sum ACM & 49.5 & 98.1 & 43.5 & 96.4 & 0.5 & 5.5 & 0.9 \\
\hline Sum CCM & 61.6 & 1.3 & 58.6 & 26.1 & 39.8 & 66.2 & 15.6 \\
\hline Sum SM & 5.5 & 2.3 & 3.3 & 6.8 & 66.8 & 31.0 & 83.1 \\
\hline Sum TL & 0 & 90.5 & 0.5 & 0 & 0.5 & 0.2 & 0.8 \\
\hline Sum other & 0.2 & 1.0 & 3.6 & 0 & 1.1 & 2.5 & 2.8 \\
\hline
\end{tabular}

following sequence: right fore (RF), left fore $(\mathrm{LF})$, right hind (RH), and left hind (LH).

Case 1: A cow without systemic reaction (rectal temperature $38.7^{\circ} \mathrm{C}$ ), with a swollen, painful, and firm RH quarter. The secretion is discoloured and contains clots. The cow was treated for mastitis in the same quarter 14 days ago. The CMT reactions are $1,1,5,3$.

Case 2: A cow with systemic reaction (rectal temperature $40.3{ }^{\circ} \mathrm{C}$ ), with a swollen LF teat and warm, painful, and swollen LF quarter. On the LF teat, there is a 3-day-old injury close to 
the teat orifice. The secretion is watery with clots. The CMT reactions are 2, 5, 2, 3 .

Case 3: A heifer without systemic reaction (rectal temperature $39.0^{\circ} \mathrm{C}$ ) that calved yesterday. At the first milking postpartum, the secretion of the LH quarter was purulent and yellow with a foul odour. Now, there is a marked physiological udder oedema, which makes it difficult to palpate the quarter. The secretion from the LH quarter has not changed since yesterday, and the secretions from the remaining quarters are colostrum-like. The CMT reactions are 2, 3, 3,5 .

Case 4: A cow with a slight systemic reaction (rectal temperature $39.7^{\circ} \mathrm{C}$ ) that was treated for $\mathrm{ACM}$ in the RH quarter one month ago. Afterwards, no clinical signs were present. At present, the RH quarter is firm and painful, and the secretion is watery and contains clots. The secretion of the LH quarter contains flakes, but no clinical changes are detected in the quarter. The CMT reactions are 2, 1, 5, 5 .

Case 5: A cow without systemic reaction (rectal temperature $38.6{ }^{\circ} \mathrm{C}$ ) that had somatic cell counts of 750,000 and 900,000 per $\mathrm{ml}$ at the 2 previous routine examinations (approximately one and 3 months ago). Clots were observed in the secretion a few days ago. Now, clinical examination of the udder and teats and inspection of the secretion do not reveal any abnormal findings. The CMT reactions are 5, 4, 1, 2 .

Case 6: A cow without systemic reaction (rectal temperature $38.5^{\circ} \mathrm{C}$ ) being examined approximately one month prior to drying off. Yesterday, the farmer observed clots in the secretions of the RH and LH quarters. There are still clots present in the milk from those quarters, but no other clinical changes are detected. The CMT reactions are 2, 2, 5, 5 .

Case 7: A cow in peak lactation without systemic signs (rectal temperature $38.5{ }^{\circ} \mathrm{C}$ ). Streptococcus dysgalactiae was found in the secretions of the RF and LH quarters one week
Table 2. Agreement between the mastitis diagnosis made by 633 veterinary surgeons (VS) for each of 7 theoretical cases and the corresponding reference diagnosis based on standard definitions of different mastitis forms. Clinical mastitis (CM) includes acute and chronic clinical mastitis. (SM: subclinical mastitis).

\begin{tabular}{lcc}
\hline Case no. & $\begin{array}{c}\text { Reference } \\
\text { diagnosis }\end{array}$ & $\begin{array}{c}\text { Diagnosis made by VS } \\
\text { in agreement } \\
\text { with reference } \\
\text { diagnosis (\%) }\end{array}$ \\
\hline 1 & CM & 99.7 \\
2 & CM & 98.6 \\
3 & CM & 97.5 \\
4 & CM & 99.2 \\
5 & SM & 66.6 \\
6 & CM & 71.7 \\
7 & SM & 83.1 \\
\hline
\end{tabular}

ago. No abnormal clinical changes are present in the udder and teats. CMT reactions are 3, 1, $1,2$.

\section{Data processing and statistical methods}

An optical reader transferred the responses in the questionnaire to a data file. The further processing of data was carried out using SAS (SAS Institute, Inc.) and Microsoft Excel (Microsoft Corporation).

The distribution of diagnoses among subgroups of the variables under study was compared using the chi-square test.

\section{Results}

Table 1 shows the percentage distribution of the various diagnoses and combinations of diagnoses that were given by the veterinary surgeons for the 7 cases.

In Table 2, ACM and CCM are unified to the diagnosis clinical mastitis (CM), and the diagnoses made by the veterinary surgeons for each of the 7 cases of mastitis are compared with the corresponding reference diagnoses based on the definitions of the mastitis forms. The per- 
Table 3. Agreement between the mastitis diagnosis made by 633 veterinary surgeons (VS) for each of five theoretical cases of clinical mastitis and the corresponding reference diagnosis based on standard definitions for different mastitis forms. The diagnostic alternatives in the National Health Card System for Cattle (NHCSC) are acute clinical mastitis (ACM) and chronic clinical mastitis (CCM).

\begin{tabular}{llc}
\hline Case no. & $\begin{array}{c}\text { Reference } \\
\text { diagnosis }\end{array}$ & $\begin{array}{c}\text { Diagnosis made by VS } \\
\text { in agreement } \\
\text { with reference } \\
\text { diagnosis (\% }\end{array}$ \\
\hline 1 & ACM & 49.6 \\
2 & CCM & 61.6 \\
3 & ACM & 98.1 \\
4 & CCM & 58.6 \\
6 & ACM & 96.3 \\
\hline
\end{tabular}

${ }^{1}$ Information supplied on Case 1 may justify either ACM or $\mathrm{CCM}$ as the reference diagnosis.

2 Subacute clinical mastitis would be the correct reference diagnosis; this is not a separate alternative in NHCSC.

centage of cases for which the veterinary surgeons used the reference diagnosis was 93.3 when $\mathrm{CM}$ was the reference diagnosis (Case 1, Case 2, Case 3, Case 4, and Case 6), and 74.9 when SM was the reference diagnosis (Case 5 and Case 7).

Table 3 comprises cases with ACM or CCM as the reference diagnosis and shows, for each case, the proportion of veterinary surgeons who reported the reference diagnosis. For Case 1, it could be questioned whether ACM or CCM was the appropriate reference diagnosis, and both alternatives are therefore included in Table 3. Taking all cases with ACM as the reference diagnosis into account (with the exception of Case 1), the proportion of concordant answers was $66.7 \%$ when the case of subacute clinical mastitis (Case 6) was included in addition to Case 2 and Case 4 and $97.2 \%$ when Case 6 was not included.

Table 4 shows the distribution of diagnoses for Case 3 and Case 4 as made by the veterinary surgeons that preferred ACM or CCM as their diagnosis for Case 1. The distribution did not differ significantly between the 2 groups of veterinary surgeons, either for Case 3 or Case 4 . Certain diagnoses (for both cases, SM and $\mathrm{ACM}+\mathrm{SM}$, and for Case 3, ACM+CCM) were used by only a few veterinary surgeons and these diagnoses were therefore pooled in the chi-square tests.

The distribution of diagnoses for Case 6 and Case 7 made by the veterinary surgeons that preferred CCM or SM as the single diagnosis for Case 5 is shown in table 5 . The proportion of veterinary surgeons that preferred CCM for Case 6 and Case 7 was significantly greater among those who used CCM for Case 5 as com-

Table 4. Percentage distribution of diagnoses for Case 3 and Case 4 made by veterinary surgeons that used either acute clinical mastitis $(A C M)(n=230)$ or chronic clinical mastitis $(C C M)(n=297)$ as their sole diagnosis for Case 1. (SM: subclinical mastitis).

\begin{tabular}{lcccccc}
\hline \multirow{2}{*}{ Case no. } & \multirow{2}{*}{$\begin{array}{c}\text { Diagnosis } \\
\text { for Case 1 }\end{array}$} & \multicolumn{5}{c}{ Diagnosis for Case 3 or Case 4 } \\
\cline { 3 - 7 } $3^{1}$ & ACM & CCM & ACM+CCM & SM & ACM+SM \\
\hline $4^{2}$ & ACM & 43.0 & 54.3 & 0.9 & 0.9 & 0.9 \\
& CCM & 37.4 & 59.6 & 1.7 & 1.3 & 0 \\
\hline & ACM & 73.5 & 2.2 & 20.0 & 4.3 & 0 \\
& CCM & 74.4 & 3.7 & 16.6 & 1.3 & 4.0 \\
\hline
\end{tabular}

$1 \chi^{2}=1.907, \mathrm{df}=2, \mathrm{p}=0.385$ (the 3 last columns pooled in the analysis)

$2 \chi^{2}=2.180, \mathrm{df}=3, \mathrm{p}=0.536$ (the 2 last columns pooled in the analysis) 
Table 5. Percentage distribution of diagnoses for Case 6 and Case 7 made by veterinary surgeons that used either chronic clinical mastitis $(C C M)(n=197)$ or subclinical mastitis $(S M)(n=364)$ as their sole diagnosis for Case 5.

\begin{tabular}{lcccccc}
\hline \multirow{2}{*}{ Case no. } & \multirow{2}{*}{$\begin{array}{c}\text { Diagnosis } \\
\text { for Case 5 }\end{array}$} & \multicolumn{5}{c}{ Diagnosis for Case 6 or Case 7 } \\
\cline { 3 - 7 } & $\mathrm{ACM}^{1}$ & $\mathrm{CCM}$ & $\mathrm{SM}$ & $\mathrm{CCM}+\mathrm{SM}$ & Other $^{2}$ \\
\hline $6^{3}$ & $\mathrm{CCM}$ & 4.1 & 75.1 & 14.7 & 2.5 & 3.6 \\
& $\mathrm{SM}$ & 5.2 & 56.6 & 29.4 & 4.4 & 4.4 \\
\hline $7^{4}$ & $\mathrm{CCM}$ & 1.0 & 20.3 & 71.6 & 5.1 & 2.0 \\
& $\mathrm{SM}$ & 0.3 & 7.7 & 84.3 & 1.1 & 6.6 \\
\hline
\end{tabular}

${ }^{1}$ ACM: Acute clinical mastitis.

${ }^{2}$ Other: Other diseases of udder or teats than mastitis and teat lesions.

${ }^{3} \chi^{2}=20.069, \mathrm{df}=4, \mathrm{p}<0.001$

${ }^{4} \chi^{2}=30.865, \mathrm{df}=3, \mathrm{p}<0.001$ (the first and the last column pooled in the analysis)

pared with those who used SM for Case 5.

The distribution of the diagnoses made by veterinary surgeons in full-time practice was compared with the distribution of the diagnoses made by veterinary surgeons that practised only during weekends or as locums for short periods. No significant differences were observed between the 2 groups with regard to the proportion of the overall most frequently used diagnosis for the cases $(p=0.74)$, the second most frequently used diagnosis $(p=0.43)$ or the most frequently used combination of 2 diagnoses ( $p$ $=0.59$ ).

The distribution of diagnoses reported by the veterinary surgeons in the various counties of Norway was compared. When the number of respondents in a county was less than 20 they where pooled with the veterinary surgeons in an adjacent county. There was an overall significant difference between counties in the proportion of veterinary surgeons that misclassified cases of SM as CCM $(p=0.039)$. This difference was solely attributed to a significantly ( $p$ $<0.001$ ) larger proportion of cases of SM misclassified by veterinary surgeons in Troms and Finnmark (41.4\%) as compared with veterinary surgeons in the remaining counties $(22.1 \%)$. The proportion of veterinary surgeons that mis- classified cases of ACM, CCM or teat lesion did not differ significantly among the counties.

\section{Discussion}

To ensure reliable data, a disease recording system should aim at the correct classification and the complete registration of all cases of disease. A standardised examination procedure, uniform guidelines for evaluation of clinical findings, and well- defined diagnostic criteria, are prerequisites for a correct classification of diseases (Ahlbom \& Norell 1987). Ideally, a disease recording system should be able to classify different cases in great detail. However, a system for the recording of clinical diseases in the field must take into account the limitations of the diagnostic tools and procedures employed by the veterinary surgeons.

The present study was undertaken to assess the diagnostic judgement of udder diseases by the Norwegian veterinary surgeons and their use of the diagnostic alternatives available in the NHCSC. Main objectives were to study the classification of clinical versus subclinical cases of mastitis, and acute versus chronic cases of clinical mastitis. Recordings of udder diseases in the NHCSC are used for sire evaluation of Norwegian cattle bulls, for research 
purposes, and for monitoring udder health in the Norwegian dairy cow population. Diagnostic classification by veterinary surgeons of cases affected with udder diseases are therefore of considerable interest.

According to the standard definitions of the different forms of mastitis, the questionnaire described 5 cases of CM, and 2 cases of SM (Case 5 and Case 7) (Table 2). For 4 of the clinical cases (Case 1, Case 2, Case 3, and Case 4), a high percentage (between $97.5 \%$ and $99.8 \%$ ) of the veterinary surgeons reported a clinical diagnosis. In all of these cases, there were distinct changes of the secretion, and in 3, additional cardinal signs of inflammation were present. A clinical diagnosis was reported for Case 6, which suffered from CM, by only $72 \%$ of the veterinary surgeons. The secretion from 2 of the quarters of this cow contained clots, but no other clinical changes were present. The mild clinical signs, and the fact that the condition occurred toward the end of the lactation period, might explain why some of the veterinary surgeons classified this case as SM.

Case 7 was typical SM without clinical signs. Nevertheless, $17 \%$ of the veterinary surgeons failed to report SM as their diagnosis, and $17 \%$ gave a clinical diagnosis, mainly CCM, either as their sole diagnosis or in combination with SM.

Case 5 had SM at the time of attendance, and almost $67 \%$ of the veterinary surgeons applied this diagnosis. However, clots had been observed in the secretion some days earlier, and this might be the reason why $32 \%$ of the veterinary surgeons recorded the case as CM. Health card recordings are used for different purposes, including progeny testing of bulls used for artificial insemination, and it might be argued that all clinical cases of disease should be recorded even if clinical signs are no longer manifest at the time of examination. If such a routine is followed, the corresponding date of examination should be recorded. On the other hand, it might be questioned whether past clinical episodes which had not been verified by a veterinary surgeon, should be registered at all. Usually, these are mild cases, which recover without medical treatment.

In addition to $\mathrm{CM}$, which was present in one of the quarters, Case 1 had SM in another quarter. This additional diagnosis was reported by $6 \%$ of the veterinary surgeons. The NHCSC has been established for the recording of clinical cases of disease and is not suitable for the complete registration of cases of SM. A case of SM will be detected and registered in the health cards more or less by chance. The cow milk somatic cell count, which is determined every second month in Norwegian dairy cows, gives a better indication of the occurrence of SM in the dairy cow population.

Among the veterinary surgeons that reported $\mathrm{CCM}$ as their sole diagnosis for Case 5, there was a larger proportion that also used CCM for Case 7, as compared with those who used SM for Case 5. Thus, some veterinary surgeons seem to invariably misclassify cases of SM (Table 5).

According to the definitions, 3 of the cows had ACM. Case 2 showed typical signs of ACM, and this diagnosis was reported by $98 \%$ of the veterinary surgeons. Also for Case 4, a high percentage $(96 \%)$ of the veterinary surgeons reported ACM. Acute clinical mastitis had been observed in the same quarter one month earlier, but no clinical signs were present between the 2 episodes. Repeated episodes might explain why some of the veterinary surgeons $(3 \%)$ considered the case to be CCM. The term «exacerbating mastitis» is used to designate cases of mastitis characterised by clinical flare-ups from a chronic subclinical mastitis (International Dairy Federation 1987). The cow may show acute or chronic clinical signs. Exacerbating mastitis is not a separate diagnostic alternative in the 
NHCSC and it might be difficult to decide whether ACM or CCM is the appropriate choice.

In Case 6, the only clinical sign was clots in the secretion. The clots had appeared recently and the appropriate diagnosis would be subacute clinical mastitis, which is not a separate diagnostic alternative in the NHCSC. Given the existing alternatives, it would be most appropriate to consider ACM as including subacute as well as peracute cases of clinical mastitis. However, only $6 \%$ of the veterinary surgeons used $\mathrm{ACM}$, while $66 \%$ chose CCM. Obviously, the majority of the veterinary surgeons associated the mild clinical signs with CCM even though the condition was of recent origin. That this is so seems to be confirmed by the results for Case 4 . Apart from the quarter, which showed marked acute signs of inflammation, this cow had subacute clinical mastitis in another quarter. The latter condition was obviously assessed as CCM by many veterinary surgeons, because $22 \%$ reported both ACM and CCM for Case 4 . Case 1 showed acute local signs, but no systemic reaction. Given this information alone, the case should have been classified as $\mathrm{ACM}$, and this alternative was reported by $50 \%$ of the veterinary surgeons. However, the cow had been treated for mastitis in the same quarter 14 days earlier. No information was given on its condition during the subsequent period. Thus, there was reason to perceive the condition as being a more or less continuous clinical process. Obviously, many veterinary surgeons did so, because $62 \%$ reported CCM.

Case 3 was a case of heifer mastitis, which the farmer became aware of at the time of calving. The appearance of the secretion indicated that the condition had existed for some time, and $59 \%$ of the veterinary surgeons reported CCM. However, it was difficult to decide whether the duration of the clinical condition was sufficiently long to justify CCM. Also ACM, which was reported by $39 \%$ of the veterinary surgeons, could hardly be considered an incorrect diagnosis.

In order to reveal any possible systematic associations between the individual veterinary surgeon's choice of clinical diagnosis for the different cases, the alternatives reported for Case 1, Case 3, and Case 4 were compared. Whether the veterinary surgeons preferred ACM or CCM for Case 1 was not associated with their choice of diagnosis for Case 3 or Case 4 (Table 4).

Although only one quarter of Case 1 showed clinical signs, $11 \%$ of the veterinary surgeons reported both ACM and CCM. The use of combinations of 2 or 3 diagnoses probably resulted from great uncertainty regarding the appropriate diagnosis. In 1995, 5.4\% of all cases of udder disease recorded in the NHCSC were given combined diagnoses (S. Sviland, unpublished data). In only $0.5 \%$ of the cases was the combination of ACM and CCM used, and in $4.1 \%$ teat lesion was recorded in combination with various forms of mastitis.

One of the main objectives of this study was to examine the extent to which veterinary surgeons pay attention to teat lesions when these occur together with $\mathrm{CM}$. According to the data from the NHCSC, teat lesion is the fifth most frequent diagnosis reported in dairy cows. The lesions vary from minor scratches to serious injury affecting the milk flow. Usually, the most serious cases are treated by veterinary surgeons. Teat lesion is frequently followed by an infection of the quarter in question (Agger \& Willeberg, 1986), and a veterinary surgeon is usually not contacted until clinical signs of mastitis appear. Apart from the main diagnosis, a cow may concomitantly suffer from one or more additional diseases, and it could be questioned just how carefully veterinary surgeons record multiple diagnoses in the same cow in the health card. In Case 2 both ACM and a teat 
lesion were present. Ninety-one percent of the veterinary surgeons diagnosed teat lesion, mainly in combination with ACM or CCM.

Apart from the typical cases of ACM, there seems to be some variation in the classification of clinical cases of mastitis in the NHCSC. When using health card data, one should carefully consider whether the diagnoses ACM and CCM should be used separately or whether the use of $\mathrm{CM}$, encompassing both $\mathrm{ACM}$ and CCM, would be a better alternative.

The classification of cases of udder disease by the veterinary surgeons did not vary significantly between counties. One exception, however, was that the proportion of veterinary surgeons who misclassified the cases of SM as CCM was significantly larger in Troms and Finnmark than in the remaining counties. A possible explanation is that within some groups of veterinary surgeons, certain diagnostic criteria, which deviate from the prevailing definitions might have become established.

The proportion of respondents to the questionnaire was $71 \%$. However, several of the veterinarians who received the questionnaire, especially in Oslo and Akershus counties, were not engaged in large animal practice at all. Thus, the percentage of respondents among those who were occupied full-time or part-time in bovine practice was greater than 71 . The literature indicates that mail surveys often produce a proportion of respondents of only $40 \%-50 \%$, but that it should be greater than $70 \%$ for results to be valid (Martin et al. 1987). The risk for selection bias increases with a high proportion of non-responders.

\section{Conclusions}

Typical cases of CM with the presence of abnormal secretion as well as other clinical signs of inflammation were correctly classified as CM by almost $100 \%$ of the veterinary surgeons. However, 2 cases of SM, and one case in the fi- nal stage of lactation with clots in the secretion as the only clinical sign, were misclassified as $\mathrm{CM}$ and SM, respectively, by several veterinary surgeons.

Of the clinical cases, those showing marked local and systemic signs were correctly classified as ACM by almost all veterinary surgeons. In the absence of a separate alternative for subacute clinical mastitis in the NHCSC, one should expect such cases to be reported as ACM. However, only $6 \%$ classified the subacute case in the study as ACM, $66 \%$ reporting $\mathrm{CCM}$, and $23 \%$ using SM as their sole diagnosis.

In the field, veterinary surgeons are occasionally faced with cases of mastitis in which the duration of the condition is uncertain, and ascertaining whether or not chronic clinical signs are present is difficult. Thus, it is not easy to decide whether the proper diagnosis is ACM or CCM. Moreover, the definitions of ACM and $\mathrm{CCM}$ do not draw a precise borderline between these diagnoses in terms of the duration and character of the clinical signs. For 2 of the clinical cases information supplied was not sufficiently detailed to conclude whether ACM or CCM was the correct diagnosis

To improve the quality of the recordings of the NHCSC, the formulation of more precise diagnostic-criteria should be considered. It should be clarified whether subacute clinical mastitis, which is not a separate diagnostic alternative in the NHCSC should be recorded as ACM or $\mathrm{CCM}$. Furthermore, the specification of criteria to enable a uniform assessment of ACM versus $\mathrm{CCM}$ would be valuable.

\section{Acknowledgements}

Valuable support in the distribution of questionnaires and the registration of data was received from the Norwegian Cattle Health Services and the Norwegian Red Cattle Breeding Organisation 


\section{References}

Agger JF, Willeberg P: Epidemiology of teat lesions in a dairy herd. II Associations with subclinical mastitis. Nord. Vet. Med. 1986, 38, 220-232.

Ahlbom A, Norell S: Grunderna i epidemiologi. (Basic concepts of epidemiology). Studentlitteratur, Lund, Sweden. 1987, p. 30.

Anonymous: Bovine Mastitis. Definition and Guidelines for Diagnosis. International Dairy Federation, Brussels, Belgium. 1987, pp. 1-2.

Anonymous: Helsekortordninga 1995. (Annual report from the Norwegian Health Card System for Cattle 1995.) Norsk Veterinærtidsskrift, 1996, 108, 395-405.

Anonymous: Jursjukdommer hos ku. (Udder diseases in the cow). Norwegian School of Veterinary Science. Department of Obstetrics, Oslo, Norway. 1991, p. 7.

Anonymous: Mastitis can take on several forms. Udder Topics, National Mastitis Council. 1996, 19, (4), 1.

Erb HN, Heinrichs AJ, Woods RE, Sisco WM: Testretest repeatability of the National Animal Health Monitoring System Dairy Heifer Health Report in New York and Pennsylvania, USA. Prev. Vet. Med. 1996, 25, 291-300.

Klastrup O, Schmidt Madsen P: Nordiske rekommendationer vedrørende mastitisundersøgelser af kirtelprøver. (Nordic recommendations for examination of milk samples from quarters suffering from mastitis.) Nord. Vet.-Med. 1974, 26, 197204.

Martin SW, Meek AH, Willeberg P: Veterinary Epidemiology. Principles and Methods. Iowa State University Press, Ames, IO, USA. 1987, p. 155.

Microsoft Corporation: Microsoft Excel for Windows 95. Redmond, WA, USA. Version 7.0a.

SAS Institute Inc: Statistical Analyse System. Cary, NC, USA. Release 6.12.

Schalm OW, Carrol EJ, Jain NC: Bovine Mastitis. Lea and Febiger, Philadelphia, PA, USA. 1971, p. 1.

Schukken YH, van de Geer D, Grommers GJ, Brand $A$ : Repeatability of questionnaire data from dairy farms. Prev. Vet. Med. 1989, 7, 31-38.

\section{Sammendrag \\ Praktiserende veterincerers bruk av diagnosealterna- tiver ved registrering av jursjukdommer i det norske helsekortsystemet for storfe.}

Et spørreskjema som inneholdt beskrivelse av 7 jursjukdomskasus, ble sendt ut til 890 veterinærer i Norge. Tilfellene skulle klassifiseres i henhold til de diagnostiske alternativene som finnes i helsekortsystemet for storfe. Helsekortregistreringene blir benyttet til avkomsgransking av avlsokser, til sjukdomsovervåkning og til forskningsformål. Hensikten med studien var å vurdere kvaliteten av helsekortregistreringene for jursjukdommer. Spørreundersøkelsen ble besvart av 633 veterinærer. Fire kliniske mastittilfeller med unormal melk og andre inflammasjonssymptomer ble korrekt klassifisert som klinisk mastitt av nesten alle veterinærene. Et tilfelle som befant seg i sluttlaktasjonen, og hadde slintrer i melka som eneste kliniske symptom, ble ikke klassifisert som klinisk av mer enn $25 \%$ av veterinærene. Et typisk subklinisk tilfelle ble klassifisert som subklinisk av $83 \%$ av veterinærene, mens $16 \%$ diagnostiserte tilfellet som kronisk klinisk mastitt. Et annet subklinisk tilfelle, der det var gitt opplysninger om funn av slintrer i melka for noen dager siden, klassifiserte $66 \%$ av veterinærene som subklinisk mastitt, men nesten $40 \%$ anga klinisk mastitt, enten som eneste diagnose eller i kombinasjon med subklinisk mastitt. De kliniske tilfellene der det forelå allmennpåkjenning og tydelige lokale inflammasjonssymptomer, ble korrekt klassifisert som akutt klinisk mastitt av $96 \%-98 \%$ av veterinærene. I helsekortsystemet for storfe registreres klinisk mastitt enten som akutt klinisk eller kronisk klinisk mastitt. Et tilfelle med subakutt klinisk mastitt ble diagnostisert som kronisk klinisk mastitt av $66 \%$ og som akutt klinisk mastitt av $6 \%$. I to tilfeller var det ikke mulig, på grunnlag av opplysninger oppgitt i spørreundersøkelsen, å avgjøre om den korrekte diagnosen var akutt eller kronisk klinisk mastitt. I begge tilfeller var hvert av disse alternativene benyttet av mer enn $43 \%$ av veterinærene. En speneskade som opptrådte samtidig med akutt klinisk mastitt hos samme ku, ble angitt av $91 \%$ av veterinærene.

\section{(Received February 26, 1999; accepted September 28, 1999.)}

Reprints may be obtained from: S. Sviland, National Veterinary Institute, P.O.Box 8156 Dep., N-0033 Oslo, Norway. E-mail: stale.sviland@vetinst.no, fax: 47226009 81, tel: 4722964657. 